\title{
Was the Malvinas/Falklands a Diversionary War? A Prospect-Theory Reinterpretation of Argentina's Decline
}

\author{
Luis L. Schenoni $\mathbb{D}$, Sean Braniff, and Jorge Battaglino
}

\begin{abstract}
Why did Argentina risk seizing the Malvinas/Falkland Islands by force in 1982, provoking a war against Great Britain, and what are the larger implications of this case? We revisit this influential episode using counterfactual analysis to interpret newly declassified declarations of high-ranking state officials involved in the decision to occupy the islands. These sources cast doubt on the diversionary-war and miscalculation theses of the Malvinas/ Falklands War, among other extant interpretations. Evidence suggests long-term power dynamics and prospect theory better explain Argentine foreign policy behavior leading to the war. Due to aversion to tangible losses, the leadership of waning states like Argentina might favor risky military strategies despite their low expected utility. These biases may provoke a war if decision-making groups are small and isolated from de-biasing influences. Our explanation illustrates the value of prospect theory to understand why certain declining states behave aggressively and more plausibly explains the Malvinas/Falklands War when confronted to set-theoretic counterfactual analysis.
\end{abstract}

Domestic factors underlie two prominent narratives for Argentina's instigation of the Malvinas/Falklands War. The first, the diversionary-war thesis, argues the 1982 Argentine invasion of the British-occupied islands was the last strategy of a contested military regime. Rising unpopularity at home, so the story goes, drove the military junta to seek a rally round-the-flag effect to boost its domestic legitimacy. The second narrative, the miscalculation thesis, argues the military regime erred in assuming Britain would not respond-or would respond more mildly-to Argentine action in the islands and the United States would intervene to avert a war. Accurate predictions of state behavior can be difficult, proponents of this thesis argue, and Buenos Aires's steps were a clear example of the difficulty of navigating the fog and friction of foreign policy in an uncertain environment.

Luis L. Schenoni is a PhD candidate at the University of Notre Dame. Sean Braniff is an assistant professor at the United States Air War College. Jorge Battaglino is a research fellow at CONICET and associate professor at Universidad Torcuato Di Tella.

Current Address: Luis L. Schenoni an assistant professor at the Centro de Investigacion y Docencia Económicas (CIDE), Mexico City. 
These two narratives have carried the day in explaining the 1982 war, but documents declassified in 2012, including statements by Argentina's military leaders involved in the decision to seize the Malvinas/Falklands, directly contradict the conventional wisdom. Revisiting this case has since become imperative, as the Malvinas/Falklands War "is the archetypal case of diversionary war." Also contributing to the perennial life span of these theses is that alternative explanations have failed to challenge them. In this article, we offer one such alternative argument and test it against diversionary-war, miscalculation, and other extant arguments. We contend that the roots of the military junta's decision lie not in domestic factors alone but have systemic origins and individual-level components as well. In short, Argentina's relative decline led to the proliferation of a loss frame among decision makers, which better explains a long series of offensive actions aiming to restore the country's standing in the region, including the seizure of the Malvinas/Falklands.

The line from regional decline to war, however, cannot be drawn without two additional points. The first is the role of lost territory. Argentines were convinced they had suffered tangible loss, and therefore failed to renormalize their perception of territorial boundaries. The Malvinas/Falklands thus became one of the few focal points in the country's endeavors to recoup losses. The second point lies in the decision-making structure of the regime: the military junta was insulated from state institutions such as intelligence agencies and civilian ministries that could have served as debiasing mechanisms. Absent their input, the small cadre of military elites running the country were more prone to the risk-acceptant decisionmaking patterns typical of individuals who have suffered loss.

This explanation better fits recently declassified evidence from a one-year investigation on the causes and conduct of the war conducted by the Argentine government between 1982 and 1983. The Commission for the Analysis and Evaluation of the Responsibilities in the South Atlantic Conflict-also known as Rattenbach Commission-produced a summary report, which was leaked to the press in late 1983. However, declassification of thousands of documents used to produce the report occurred only after a 2012 presidential decree. These documents comprise every official directive issued during the period leading to the war and hundreds of interviews with high-ranking state officials, including depositions of the three members of the junta, the military officials who planned the operation, ministries, diplomats, and others. The declarations were recorded within a one-year period after the war, under secrecy and oath, and were triangulated by the investigators, providing fresh and reliable evidence. Moreover,

'Amy Oakes, "Diversionary War and Argentina's Invasion of the Falkland Islands," Security Studies 15, no. 3 (July-September 2006): 432. 
Lieutenant-General Benjamín Rattenbach, chairman of the commission, asked directly about the diversionary-war, miscalculation, and other hypotheses already circulating at the time. These recently declassified depositions provide critical evidence to assess the mindset of decision makers, but they have yet to be incorporated into the political science debate on this topic. ${ }^{2}$

Reassessing the foreign policy of the Argentine military helps us understand the type of behavior leaders in declining powers might exhibit under similar pressures. International relations theories dealing with the effects of power shifts in interstate war have proposed that declining states are more war prone than average, but the literature remains opaque in explaining why leaders in these states would prefer the uncertainty of war to a peaceful accommodation, and why variation in bellicosity exists among declining powers. This article identifies conditions under which relative decline may lead to war. We propose that the risk-acceptant behavior of foreign policy elites in declining states-which would be underpredicted by standard rationality assumptions-is better anticipated by an alternative paradigm in cognitive psychology: prospect theory. If the leaders of declining states think and behave in the way predicted by prospect theory-as individuals have been proven to in the face of losses through experimental studiesthen war may become a reasonable strategy for them.

To make our case, we follow this introduction with three substantive sections. We begin by proposing that explanations for the foreign policy of some declining states might be best grounded in prospect theory. Furthermore, we discuss how perceived tangible losses-for example, territorial losses-provide a focal point against which leaders measure their state's standing, and how the behavioral expectations of prospect theory can be aggregated to the level of state behavior when the institutional setting insulates decision makers from the potentially de-biasing influences of a larger bureaucracy. The next section turns to the case under consideration, as we use counterfactual analysis to rule out the common narratives that the Argentine junta attacked the Malvinas/Falklands for diversionary purposes or due to miscalculation. Finally, we demonstrate our case in detail in the fourth section using a set-theoretic counterfactual structure, which allows us to be explicit about the observational implications of our own argument and provide systematic evidence in its favor. We conclude the article with implications for theory and future research.

\footnotetext{
${ }^{2}$ Archival material cited throughout this article is available online at: https://www.casarosada.gob.ar/ informacion/archivo/25773-informe-rattenbach. We try to compensate for the unavailability of a translation of all these interviews to the English language by providing an appendix with translated selected fragments of key interviews (See Appendix 1, available upon request).
} 


\section{Declining States and Risk Acceptance}

Classic scholarship on power shifts has systematically found the propensity for war is higher when relative power dynamics are in flux. A. F. K. Organski and Jacek Kugler conclude succinctly that the "differences in rates of growth" are "the fundamental problem that sets the whole system sliding almost irretrievably toward war." ${ }^{3}$ Robert Gilpin takes a long view of history in his argument that "disequilibrium replaces equilibrium, and the world moves toward a new round of hegemonic conflict." ${ }^{4}$ More recent scholarship has built upon early power transition theorists by focusing not just on changing power dynamics, but on the effect of decline specifically. Dale C. Copeland concludes declining powers' fear of the future is the "common cause" of major war "across the millennia." Similarly, Graham Allison cites the fear of challengers on states that are in relative decline as a major cause of war since the fifteenth century. ${ }^{6}$ This proposition has been applied to major and minor states alike, suggesting regional powers respond to decline as great powers do. ${ }^{7}$

Throughout this literature, decline is usually defined as a decrease in a state's ordinal ranking in material capabilities among its peer competitors during a given period. Here we adopt a similar basic definition of decline, ${ }^{8}$ since material measures have been sufficient to establish the aforementioned empirical regularity. Yet, relative material decline is intrinsically intertwined with broader concerns about status. ${ }^{9}$ Although there is no legal hierarchy in international politics, states seek the greatest degree of autonomy and leverage within their sphere of influence ${ }^{10}$ and thus are "reluctant to surrender their influence and control over institutions, territory, and markets." ${ }^{11}$ Regaining status or prestige could be a sufficient justification

\footnotetext{
${ }^{3}$ A. F. K. Organski and Jacek Kugler, The War Ledger (Chicago: University of Chicago Press, 1980), 61.

${ }^{4}$ Robert Gilpin, War and Change in International Politics (Cambridge: Cambridge University Press, 1981), 210.

${ }^{5}$ Dale C. Copeland, The Origins of Major War (Ithaca, NY: Cornell University Press, 2000), 1.

${ }^{6}$ Graham Allison, Destined for War: Can America and China Escape Thucydides's Trap? (Boston, MA: Houghton Mifflin Harcourt, 2017); see also Stacie E. Goddard, When Right Makes Might: Rising Powers and World Order (Ithaca, NY: Cornell University Press, 2018).

${ }^{7}$ For an application of power transition theory to all regions of the world, see: Douglas Lemke, Regions of War and Peace (Cambridge: Cambridge University Press, 2002). For a more particular application to the case we are analyzing, see Luis Leandro Schenoni, "The Argentina-Brazil Regional Power Transition," Foreign Policy Analysis 14, no. 4 (October 2018): 469-89.

${ }^{8}$ We follow other scholars in using material decline vis-à-vis a peer competitor over a period of more than five years. See Paul K. MacDonald and Joseph M. Parent, Twilight of the Titans: Great Power Decline and Retrenchment (Ithaca, NY: Cornell University Press, 2018), 5; Joshura R. Itzkowitz Shifronson, Rising Titans, Falling Giants: How Great Powers Exploit Power Shifts (Ithaca, NY: Cornell University Press, 2018), 15.

'Reinhard Wolf, "Respect and Disrespect in International Politics: The Significance of Status Recognition," International Theory 3, no. 1 (March 2011): 123; Tudor A. Onea, "Between dominance and decline: status anxiety and great power rivalry," Review of International Studies 40, no. 1 (2014): 125-52.

${ }^{10}$ William C. Wohlforth et al., "Moral Authority and Status in International Relations: Good States and the Social Dimension of Status Seeking," Review of International Studies 44, no. 3 (July 2018): 526-46.

"William R. Thompson, "Status Conflict, Hierarchies, and Interpretation Dilemmas," in Status in World Politics, ed. T. V. Paul, Deborah Welch Larson, and William C. Wohlforth (Cambridge: Cambridge University Press, 2014), 244.
} 
for war, ${ }^{12}$ though examining power dynamics through a solely rational lens may lead to various possible outcomes. ${ }^{13}$ Although these outcomes may range from retrenchment and a decrease in grand strategic ambition to strategic expansion, ${ }^{14}$ the mechanisms that connect decline with subsequent state behavior remain unclear. ${ }^{15}$

In line with a broad literature in cognitive psychology, we argue that although the rationality assumption may be a good guide to state behavior in "normal" times, expected-utility theory does not work well in contexts where great losses and great risk are involved ${ }^{16}$ - precisely the conditions elites of declining states face. As the leaders of a declining state perceive tangible-for example, territorial-losses, they may bypass expected-utility reasoning. These biases can then be amplified if the decision-making arm of the state is shielded from institutional mechanisms that could otherwise de-bias it from the risk-acceptant stance of particular individuals. Overall, such a situation could lead to the type of risk-acceptant behavior better predicted by prospect theory. ${ }^{17}$ This addendum to the study of power dynamics-which even fits emotional metaphors dating back to Thucydides's account of the fear that a rising Athens sparked in Sparta ${ }^{18}$ must therefore be seriously considered as a necessary complement for the theories that predict war in contexts of power shifts.

Prospect theory, in contrast to expected-utility theory, offers a positive rather than normative account for human behavior under conditions of risk. It centers on actual cognitive processes and their behavioral corollaries without relying on "as if" assumptions that abstract complex decisionmaking processes into "useful fictions." 19 Central to prospect theory is the contention that actors view outcomes not in terms of their final utility but as losses or gains relative to a reference point. This frame helps organize

\footnotetext{
${ }^{12}$ Jonathan Kirshner, "Rationalist Explanations for War?" Security Studies 10, no. 1 (Autumn 2000): 143-150.

${ }^{13}$ Bruce Bueno de Mesquita, "Risk, Power Distributions, and the Likelihood of War," International Studies Quarterly 25, no. 4 (December 1981): 541-68.

${ }^{14}$ MacDonald and Parent, Twilight of the Titans.

${ }^{15}$ As Jack S. Levy notes in the case of preventive war, there must be a set of intervening variables or conditions that combine with the "preventive motivation" to cause war. Jack S. Levy, "Declining Power and the Preventive Motivation for War," World Politics 40, no. 1 (October 1987): 82-107.

${ }^{16}$ Jack S. Levy, "Prospect Theory, Rational Choice, and International Relations," International Studies Quarterly 41, no. 1 (March 1997): 87-112.

${ }^{17}$ Daniel Kahneman and Amos Tversky, "Prospect Theory: An Analysis of Decision Under Risk," Econometrica 47 (March 1979): 263-91.

${ }^{18}$ Graham Allison, Dale C. Copeland, and others like John J. Mearsheimer build strongly on the notion of fear, a particular state of mind that might constrain rational behavior. Studies on cognitive psychology have determined that decision making is rarely rational when this kind of anxiety is a driver of behavior. Cf. Rose McDermott, "The Feeling of Rationality: The Meaning of Neuroscientific Advances for Political Science," Perspectives on Politics 2, no. 4 (December 2004): 691-706.

${ }^{19}$ Charles L. Glaser, Rational Theory of International Politics: The Logic of Competition and Cooperation (Princeton, NJ: Princeton University Press, 2010), 23; Paul K. MacDonald, "Useful Fiction or Miracle Maker: The Competing Epistemological Foundations of Rational Choice Theory," American Political Science Review 47, no. 4 (November 2003): 551-65.
} 
information and guide behavior. ${ }^{20}$ A loss or gain frame signifies an actor views an outcome not in terms of a final value but rather in comparison (as a loss or a gain) to a reference point. Critically, actors renormalize their reference point quickly after having received gains but are much slower to renormalize in the domain of losses. ${ }^{21}$

Prospect theory has some important implications for the behavior of elites in declining states. Among Jack S. Levy's six implications of prospect theory for international relations scholarship, ${ }^{22}$ we find three especially of note for the scope of our study: (1) state leaders take more risks to maintain their status; (2) they tend not to accommodate to the new status quo after suffering losses; ${ }^{23}$ and (3) because this accommodation is slow, sunk costs often influence future decision making. ${ }^{24}$ It is through these logics that a previous loss, especially a loss that is not abstract but tangible and concrete, such as territory, can become a reference point for state leaders interpreting their state's decline and a focal point for trying to reverse it. Historical precedent of territorial boundaries, therefore, looms large in the minds of decision makers facing these circumstances. ${ }^{25}$

Elites of declining states facing tangible losses are therefore, by definition, in a situation prone to risk-acceptant behavior. This reinforces our intuition that studies of foreign policy decision making should consider the psychology of the elites who make those decisions. ${ }^{26}$ Individuals "conserve cognitive resources in seeking and processing information" 27 and therefore the factors that affect their thinking are key. ${ }^{28}$

Yet, how can the individual-level implications of prospect theory be aggregated to the state level ? $^{29}$ One way to deal with this problem would be to simply abstract the foreign policy decisions of elites into state actions, ${ }^{30}$ and indeed attributing person-like attributes to the state has a

\footnotetext{
${ }^{20}$ Kahneman and Tversky, "Prospect Theory," 290.

${ }^{21}$ Soul Park and Kimberly Peh, "Leveraging towards Restraint: Nuclear Hedging and North Korea's Shifting Reference Points during the Agreed Framework and the Six-Party Talks," European Journal of International Security (July 2019 [online]): doi:10.1017/eis.2019.15.

${ }^{22}$ Levy, "Prospect Theory, Rational Choice, and International Relations," 93.

${ }^{23}$ Robert Jervis, "Political Implications of Loss Aversion," Political Psychology 13, no. 2 (June 1992): 187-204.

${ }^{24}$ Jeffrey W. Taliaferro, Balancing Risks: Great Power Intervention in the Periphery (Ithaca, NY: Cornell University Press, 2004), 33-34.

${ }^{25}$ Scott F. Abramson and David B. Carter, "The Historical Origins of Territorial Disputes," American Political Science Review 110, no. 4 (November 2016): 675-98; Alison Ledgerwood and Amber E. Boydstun, "Sticky Prospects: Loss Frames Are Cognitively Stickier than Gain Frames," Journal of Experimental Psychology: General 143, no. 1 (February 2014): 376-85.

${ }^{26}$ Robert Jervis, How Statesmen Think: The Psychology of International Politics (Princeton, NJ: Princeton University Press, 2017); Elizabeth N. Saunders, Leaders at War: How Presidents Shape Military Interventions (Ithaca, NY: Cornell University Press, 2011); John M. Schuessler, Deceit on the Road to War: Presidents, Politics, and American Democracy (Ithaca, NY: Cornell University Press, 2015).

${ }^{27}$ Jervis, How Statesmen Think, 41.

${ }^{28}$ Rose McDermott, Risk-Taking in International Politics: Prospect Theory in American Foreign Policy (Ann Arbor: University of Michigan Press, 1998), 34.

${ }^{29}$ Levy, "Prospect Theory, Rational Choice, and International Relations," 102.

${ }^{30}$ In this sense it is no more problematic to aggregate prospect theory to state behavior than it is to argue that a state "thinks" rationally. Jeffrey W. Taliaferro makes this point, among others, in his study using prospect
} 
long history in international relations literature. ${ }^{31}$ However, in the vast majority of cases, state behavior is an aggregation of individual behaviors. Because of this, the rules of aggregation taking place in any political system are key to determine the impact of psychological factors.

Executive foreign policy elites rarely operate in isolation and other institutions-for example, legislatures-or "foreign policy bureaucracies, especially intelligence services," may counter their natural cognitive biases. ${ }^{32}$ It is not that secrecy and executive isolation cannot happen in democracies, ${ }^{33}$ nor that robust foreign policy bureaucracies present decision makers with unbiased information; ${ }^{34}$ rather, it will be more likely within a robust and diverse decision-making environment that the decision makers will, according to Robert Jervis, "consider alternative explanations of specific bits of data and think more carefully about the beliefs and images that underlie their policies." 35 Because of this, we argue the implications of prospect theory are more likely to affect state behavior in decision-making environments in which foreign policy elites are shielded from state institutions that typically influence foreign policy, such as occurred with Argentina's military junta. ${ }^{36}$ In other words, a loss frame is more likely to take hold of decision making when negative thinking at the level of the elite is matched by a small and insulated decision group. ${ }^{37}$

theory to analyze great power peripheral interventions. "Expected utility theory and prospect theory," he notes, "by themselves, do not generate substantive predictions about international outcomes or the foreign policy behavior of states. Instead, one must embed concepts from these decision theories into specific theories of foreign policy and international politics." Taliaferro, Balancing Risks, 32-33.

${ }^{31}$ Carlos Escudé, "Anthropomorphic Fallacy in International Relations Discourse" (working paper 94-06, Weatherhead Center for International Affairs, Harvard University, 1994), 1-20; the argument was popularized by Alexander Wendt, "The State as a Person in International Theory," Review of International Studies 30, no. 2 (April 2004): 289-316.

32 Jervis, How Statesman Think, 138-39.

${ }^{33}$ Sebastian Rosato, "The Flawed Logic of Democratic Peace Theory," American Political Science Review 97, no. 4 (November 2003): 587.

${ }^{34}$ Robert Jervis, Why Intelligence Fails: Lessons from the Iranian Revolution and the Iraq War (Ithaca, NY: Cornell University Press, 2010); Uri Bar-Joseph and Rose McDermott, Intelligence Success and Failure: The Human Factor (New York: Oxford University Press, 2017).

${ }^{35}$ Robert Jervis, Perception and Misperception in International Politics, new ed. (Princeton, NJ: Princeton University Press, 2017), 416.

${ }^{36}$ In noting a role in our argument for the junta's isolation from influences that may have helped de-bias it from cognitive shortcuts, we do not mean to imply that theories grounded in prospect theory have no role in analyzing the foreign policy decisions of other regime types. Indeed, scholars have employed prospect theory to studies of a variety of regimes. McDermott, Risk-Taking in International Politics; Taliaferro, Balancing Risks; Kurt Weyland, The Politics of Market Reform in Fragile Democracies: Argentina, Brazil, Peru, and Venezuela (Princeton, NJ: Princeton University Press, 2002); Jeffrey D. Berejekian and Bryan R. Early, "Loss Aversion and Foreign Policy Resolve," Political Psychology 34, no. 5 (October 2013): 649-71; Kai He, China's Crisis Behavior: Political Survival and Foreign Policy after the Cold War (Cambridge: Cambridge University Press, 2016).

${ }^{37}$ Evidence exists that prospect theory applies not only for individuals making decisions in isolation but in-group dynamics as well. William J. Qualls and Christopher P. Puto, "Organizational Climate and Decision Framing: An Integrated Approach to Analyzing Industrial Buying Decisions," Journal of Marketing Research 26, no. 2 (May 1989): 179-92; Katsuhiko Shimizu, "Prospect Theory, Behavioral Theory, and the Threat-Rigidity Thesis: Combinative Effects on Organizational Decisions to Divest Formerly Acquired Units," Academy of Management Journal 50, no. 6 (December 2007): 1495-514; Piers Steel and Cornelius J. König, "Integrating Theories of Motivation," Academy of Management Review 31, no. 4 (October 2006): 889-913. 


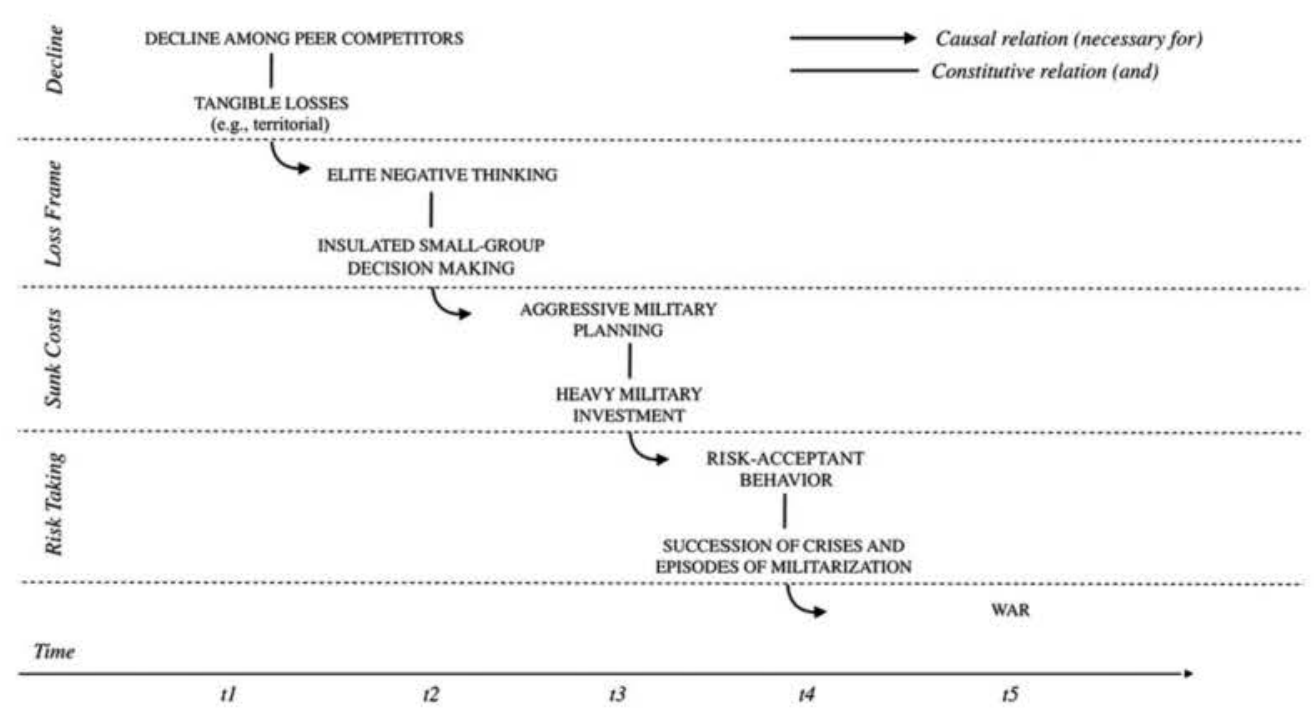

Figure 1. Mechanism linking power shifts with war.

Our basic proposed causal mechanism is depicted in Figure 1. This figure is divided into five horizontal layers or steps. ${ }^{38}$ In a first step, a state's drop in ordinal rank among peer competitors must combine with a tangible loss-for example, territory-to induce elites to think they are in the realm of losses. In a second step, the elite's negative perceptions must combine with a small and insulated decision-making structure for this loss frame to take hold of the state. In a third step, aggressive planning and military investment combine, setting the state on a path-dependent trajectory that is self-reinforced by the perception of sunk costs. This leads to risk-acceptant behavior in a fourth step, which is bound to produce suboptimal results: diplomatic crises, militarized disputes, and, at its most extreme, war as a fifth and last step. ${ }^{39}$

When we state that these steps are necessary, we do not mean each is necessary for all wars, nor do we mean they are necessary in their individual relation with each other-for example, that risk-taking behavior cannot happen in the absence of a loss frame. Instead, we argue each of these conditions are insufficient but necessary parts of a larger set of conditions that is itself unnecessary but sufficient (INUS) to produce the outcome in our case. In other words, these are necessary links of the chain that comprises

\footnotetext{
${ }^{38}$ For a similar approach that also speaks to the importance of territory and militarized disputes, see Paul D. Senese and John A. Vasquez, The Steps to War: An Empirical Study (Princeton, NJ: Princeton University Press, 2008).

${ }^{39}$ For a discussion of path dependence and self-reinforcing sequences, see James Mahoney, "Path Dependence in Historical Sociology," Theory and Society 29, no. 4 (August 2000): 507-48.
} 
our theory, which we believe sufficient, but not necessary, to explain Argentina's actions in the Malvinas/Falklands. ${ }^{40}$

Our theory betters the diversionary-war and miscalculation theses in several important respects. The diversionary-war thesis focuses on immediate causes of the 2 April invasion-for example, a 30 March demonstration against the government-yet fails to explain the initial predisposition of the junta. Conversely, the miscalculation thesis explains how biases in the junta enabled the decision but cannot explain timing. Our theory illuminates both long-term and immediate causes. ${ }^{41}$ It can explain the aggressiveness of the junta before the war in other contexts, why the decision to invade was made in late December 1981, right after Lieutenant-General Leopoldo F. Galtieri became president, reshuffling the junta, and the advancement of the invasion date from 15 May to 2 April, which was due to the unintended escalation of yet another risky episode of militarization in South Georgia Island. Also, our theory provides a necessary systemic complement to explanations that rely solely on domestic factors while also providing the psychological microfoundations explaining the individual behavior of the members of the junta. ${ }^{42}$ Despite its relative complexity, its completeness makes it more parsimonious than the alternatives.

\section{The Causes of the Malvinas/Falklands War: Reasoning Counterfactually}

Argentina waged the Malvinas/Falklands War of 1982, so the mainstream narrative goes, to boost the legitimacy of a junta, which, in turn, grossly misread the probability that London would retaliate as it did. ${ }^{43}$ This narrative, however, implies a series of counterfactuals that have not been rigorously analyzed. ${ }^{44}$

\footnotetext{
${ }^{40}$ Our causal logic is further explored in our case study section and in relation to counterfactuals. For a more abstract discussion of INUS causation, see James Mahoney, "Toward a Unified Theory of Causality," Comparative Political Studies 41, no. 4/5 (April 2008): 412-36.

${ }^{41}$ Hillel David Soifer, "The Causal Logic of Critical Junctures," Comparative Political Studies 45, no. 12 (December 2012): 1572-97.

${ }^{42}$ For the importance of combining these elements, see Norrin M. Ripsman, Jeffrey W. Taliaferro, and Steven E. Lobell, Neoclassical Realist Theory of International Relations (New York: Oxford University Press, 2016).

${ }^{43}$ Richard Ned Lebow, "Miscalculation in the South Atlantic: The Origins of the Falklands War," Journal of Strategic Studies 6, no. 1 (1983): 5-35; Max Hastings and Simon Jenkins, The Battle for the Falklands (New York: Palgrave Macmillan, 1984); Carlos J. Moneta, "The Malvinas Conflict: Analyzing the Argentine Military Regime's Decision-Making Process," in Latin American Nations in World Politics, ed. Heraldo Muñoz and Joseph S. Tulchin (Boulder, CO: Westview Press, 1984); Jack S. Levy, "Domestic Politics and War," in The Origin and Prevention of Major Wars, ed. Robert I. Rotberg and Theodore K. Rabb (Cambridge: Cambridge University Press, 1989); Jack S. Levy and Lily I. Vakili, "Diversionary Action by Authoritarian Regimes: Argentina in the Falklands/Malvinas Case," in The Internationalization of Communal Strife, ed. Manus I. Midlarsky (London: Routledge, 1992); Amy Oakes, "Diversionary War and Argentina's Invasion of the Falkland Islands"; Ross A. Miller and Özlem Elgün, "Diversion and Political Survival in Latin America," Journal of Conflict Resolution 55, no. 2 (April 2011): 192-219.

${ }^{44}$ Curiously, IR scholars who engaged with the Malvinas/Falklands War also wrote extensively about counterfactuals. Richard Ned Lebow, "What's So Different about a Counterfactual?" World Politics 52, no. 4 (July 2000): 550-85; Jack S. Levy "Counterfactuals and Case Studies," in Oxford Handbook of Political Methodology, ed. Janet M. Box-Steffensmeier, Henry E. Brady, and David Collier (New York: Oxford University Press, 2008). The Malvinas/Falklands War lends itself to counterfactual thinking. It is one of the most salient
} 
Counterfactual historical analysis is a strategy for causal inference that is beneficial when scholars face a single historical event and wish to weigh different possible explanations for a certain outcome. ${ }^{45}$ Most historical narratives about single events imply causality in the form of a set of conditions necessary for the event to take place. ${ }^{46}$ For example, saying a decline in the domestic support for the junta caused the Malvinas/Falklands invasion amounts to saying the decaying popularity of the Argentine military was a necessary condition for the war to occur, which, in turn, implies the following counterfactual: had domestic support for the junta been higher, the military would not have launched the attack. Once we make these counterfactuals explicit, the cracks in the argument become more evident, and the whole edifice of this explanation starts to crumble.

The miscalculation and diversionary-war hypotheses assume the Malvinas/Falklands War would not have been fought if the popularity of the junta had been high in March 1982 and Galtieri had properly calculated the risk of an invasion. We contend these assumptions directly contradict six key pieces of newly available evidence, which we present here and elaborate upon in the pages that follow:

1. The junta had already acted aggressively in contexts when popular support for the regime was high.

2. The junta had decided to attack two to three months before its popularity started to decline.

3. The junta had no plans for domestic psychological campaigns nor attempted to organize a rally-round-the-flag effect.

4. The Argentine military had correctly calculated in several intelligence reports that the British would respond to the attack as they did.

5. The military knew Washington would support London on 1 April, yet decided to retake the islands on 2 April. Similarly, they knew the size of the British fleet deployed on 3 April, and yet rejected several mediation proposals between then and the outbreak of hostilities one month later.

6. The plans not only foresaw a British response but also the involvement of Chile.

Put together, the evidence suggests the drive to regain the islands was independent from domestic unrest and miscalculation, and the invasion would have taken place even in the absence of those two factors.

events in recent Argentine history, it was unexpected, had a profoundly negative impact, and those responsible for the decision were in those positions of power briefly and for rather fortuitous reasons.

${ }^{45}$ James D. Fearon, "Counterfactuals and Hypothesis Testing in Political Science," World Politics 43, no. 2 (January 1991): 169-95.

${ }^{46}$ Gary Goertz and Jack S. Levy, Explaining War and Peace: Case Studies and Necessary Condition Counterfactuals (London: Routledge, 2007), 16. 
The Malvinas/Falklands invasion was not an unexpected outburst of violence of an otherwise serene Argentine military. From the mid-1970s the Argentine government had begun to regularly use the threat of invasion as part of their diplomatic strategy to regain sovereignty over the islands. At the end of 1975, tension between Argentina and Britain had increased, and at the beginning of the following year the Argentine president held meetings with the foreign minister and the three commanders of the armed forces to analyze armed options. ${ }^{47}$ Tension peaked in February 1976 when a destroyer of the Argentine Navy made several shots across the bow of the British ship Shackleton so it would not continue on its course to the Malvinas.

Additionally, after the military coup of March 1976, Argentina began to build a scientific base in the Thule Islands, a territory in dispute with Great Britain, which was later occupied by the Argentine navy. The installation continued to operate, despite protests from the United Kingdom. The Argentine government informed the British, at the end of 1976, that it was willing to intercept and eventually sink any intruder in Argentine territorial waters around the Malvinas, a policy that remained in place in the following years. Subsequently, the Argentine Navy developed and seriously considered plans for the occupation of the Malvinas with regularity. In his deposition to the Rattenbach Commission, Admiral Jorge Isaac Anaya, one of three members of the junta, declares he developed one such plan in 1977, and that his predecessor, Admiral Emilio Eduardo Massera, formally proposed it to his junta in 1978. Unlike in 1982, the two other members voted against it. $^{48}$

Also in 1978, the junta intended to capture the islands around Cape Horn and the disputed islands in the Beagle Channel-which a British court, acting as international arbitrator, had recently awarded to Chileforcing Santiago to recognize the sovereignty of Argentina over the latter. On 22 December 1978, Argentina launched Operation Sovereignty, which intended to retake the islands by force. The operation most probably would have caused full-scale war had it not been suspended twenty nautical miles off the coast of Chile due to a fierce storm. ${ }^{49}$ In the next hours the "divine" intervention of the Pope as a mediator averted the conflict, but the Argentine navy was hours-some claim minutes-away from starting a war in the Southern Cone.

\footnotetext{
${ }^{47}$ Douglas Kinney, National Interest, National Honor: The Diplomacy of the Falkland Crisis (New York, Praeger: 1989), 54; Carlos Escudé, "El trasfondo cultural de la invasión argentina de Malvinas: contenido nacionalista de la enseñanza de la geografía 1879-1986," Boletín del Centro Naval, 827 (May/August 2010): 169.

${ }^{48}$ Admiral Jorge Isaac Anaya, Declarations to the Commission for the Analysis and Evaluation of the Responsibilities in the South Atlantic Conflict [hereafter CAERCAS], vol. 4, 733.

${ }^{49}$ David R. Mares, Violent Peace: Militarized Interstate Bargaining in Latin America (New York: Columbia University Press, 2001), 138; Andrés Villar Gertner, Autonomy and Negotiation in Foreign Policy: The Beagle Channel Crisis (London: Palgrave Macmillan, 2016), 1.
} 
The Shackleton/Thule Islands incidents, Massera's proposal, and Operation Sovereignty directly refute a central counterfactual claim of the diversionary-war and miscalculation theses: that the Argentine military would not have fought a war in a climate of broad domestic support for the regime and with abundant information. In all three episodes, the Argentine military had abundant information about the deployments and war plans of their Chilean and British counterparts. Domestically, the occupation of the Thule Islands took place in a context of renowned domestic acquiescence vis-à-vis the coup, which most Argentines saw as necessary evil to achieve domestic pacification. Operation Sovereignty occurred only a few months after the Argentine soccer team had won the FIFA World Cup-arguably the most cherished accomplishment in Argentina's sports history-which resulted in the legitimization of the junta. Additionally, by mid-1978 a rise in productivity was already taking place that would lead to an impressive 10 percent annual growth in 1979, and the war against leftist organizations had already ended. Argentina lived a period of "authoritarian peace," 50 a combination of economic, social, and political stability that led to a peak of public support for the government.

A second piece of evidence further undermines the diversionary-war hypothesis: The junta made the key formal decision leading to the invasion of the islands on 5 January 1982-three months before the occupation, and at least two months before the domestic front deteriorated. To this end, a task force began to meet on 12 January and formulated the first military planning document-known as National Strategic Directive (DEMIL) 1 -which the junta later approved. The directive urged to "foresee the use of military power for the achievement of the political objective." ${ }^{51}$ DEMIL $1 / 82$, a related document, states even more clearly that "to reach successful negotiations with Britain it would be necessary to use military power" ${ }^{\prime 2}$ in order to "impose on Great Britain the acceptance of a de facto situation which will in turn lead to the full exercise of Argentine sovereignty in the Malvinas Islands." 53 The testimonies of the six officials involved in the planning - that is, the three members of the task force and the Navy Chiefs of Staff-show these were not mere military plans that could be discarded, but assertive policy recommendations. The Navy Chiefs of Staff, Rear Admirals Carlos Alberto Büsser (Marine Corps), Carlos Alfredo García Boll

\footnotetext{
${ }^{50}$ Marcos Novaro, Historia de la Argentina 1955-2010 (Buenos Aires: Siglo Ventiuno, 2010), 173.

${ }^{51}$ Argentine Government, DEMIL 1/82. Directiva de estrategia militar 1/82 (Buenos Aires: Comité Militar del Estado Mayor Conjunto, 1982), 2-5.

${ }^{52}$ CAERCAS, Informe Final, 58.

${ }^{53}$ CAERCAS, Informe Final, 147. Italics in original. Others before us have documented that the Argentine military were long waiting for the failure of negotiations with the United Kingdom to give them an excuse to attack. Juan E. Corradi, The Fitful Republic: Economy, Society, and Politics in Argentina (London: Westview Press, 1985), 141-42; Hastings and Jenkins, The Battle for the Falklands, 50.
} 
(Naval Aviation), and Gualter Oscar Allara (Fleet), all confirm the decision to carry out the invasion occurred before, during late December $1981 .^{54}$ This is in line with recent historiography asserting Galtieri conceded the invasion plans in exchange for the Navy's support for his presidency, inaugurated on 22 December $1981 .^{55}$ Interestingly, Galtieri was not facing any domestic unrest at the time. On the contrary, he was enjoying a quiet honeymoon period right before the summer holidays.

A third piece of information that contradicts the diversionary-war account relates to the military's lack of concern about domestic unrest or how the occupation would be communicated to the public-what the Argentine military called psychological action. If the main objective of the war was to influence public opinion, the junta should have analyzed how war would affect it, and carefully prepared a propaganda campaign. Yet, the attitude of the military was one of disregard. They even trusted repression to handle the unrest possibly produced by the war. ${ }^{56}$ Officials key to foreseeing the domestic impact of the war, like the minister of economy, Roberto Alemann, only knew about the occupation after it happened, on the morning of 2 April. ${ }^{57}$ The minister of the interior, Alfredo Saint Jean, was reporting to Galtieri about trade unions when he was allegedly told, "Come on, Saint Jean, you have to come with this problem precisely today?" 58 The president subsequently confided that the occupation would happen in a few hours, and asked him to do nothing and preserve the secret. The secretary of intelligence, Carlos Martínez, arguably the official in the possession of most means to organize psychological action, also knew of the plans on the night of the landing. ${ }^{59}$ The lack of any planning of the communication campaign is a central theme throughout Rattenbach's interviews.

\footnotetext{
${ }^{54}$ Rear Admiral Carlos Alfredo García Boll, Declarations to the CAERCAS, vol. 2, 292; Rear Admiral Gualter Oscar Allara, Declarations to the CAERCAS, vol. 3, 445; Rear Admiral Carlos Alberto Büsser, Declarations to the CAERCAS, vol. 5, 950.

${ }^{55}$ Benjamín García Holgado and Nicolás Taccone, "Diseño institucional e inestabilidad presidencial en autoritarismos: el Proceso de Reorganización Nacional en la Argentina (1976-1983)," Desarrollo Económico 58, no. 224 (2018): 19. In previous years the Navy had proven to be a belligerent force, sending mixed signals that spoiled resolution of existing disputes with Brazil and Chile. See Christopher Darnton, "Public Diplomacy and International Conflict Resolution: A Cautionary Case from Sold War South America," Foreign Policy Analysis (March 2019 [online]): https://doi.org/10.1093/fpa/orz003. Santiago Alles, "De la Crisis del Beagle al Acta de Montevideo de 1979: el establecimiento de la mediación en un 'juego en dos niveles,"' Estudios Internacionales 44, no. 169 (May-August 2011): 79-117.

${ }^{56}$ Without going any further, the Argentine military had successfully repressed a demonstration on 30 March. We must remember the military had suffocated a guerrilla uprising in 1976-78 that reached distant corners of the country, which had demonstrated the effectiveness of Argentine state in repressing its society. These facts and several declarations to the Rattenbach Commission disprove the thesis according to which the military could not resort to repression in March 1982. See Oakes, "Diversionary War and Argentina's Invasion of the Falkland Islands."

${ }^{57}$ Minister of Economy Roberto Alemann, Declarations to the CAERCAS, vol. 3, 539.

${ }^{58}$ Minister of the Interior Alfredo Saint Jean, Declarations to the CAERCAS, vol. 2, 227.

${ }^{59}$ Secretary of Intelligence Carlos Martínez, ibid., 216.
} 
While these facts prove the counterfactuals underlying the diversionarywar thesis are wrong, the following pieces of evidence deal a similar blow to the miscalculation hypothesis.

First, it is clear Argentina knew with precision what the British response would look like. At least six intelligence reports between 1979 and 1981 had warned about a sizable military response from Great Britain to an Argentine landing in Malvinas. For example, the Secretariat of Strategic Planning had prepared an intelligence report in 1980 that argued a war with Great Britain would ensue if Argentina decided to occupy the Malvinas. ${ }^{60}$ Also, a naval intelligence assessment at the end of 1981 held that Britain would respond with proportional force if Argentine forces disembarked on the islands. DEMIL 1 itself reads: "The United Kingdom can have a strategic military response to the occupation of the islands." ${ }^{61}$ In fact, the three members of the task force charged with producing DEMIL 1-Rear Admiral Juan José Lombardo, Major General Osvaldo García, and Brigadier Martín Plessl-warned their commanders in chief that the planning for the occupation of the islands should also include a plan for their defense. $^{62}$ All officials involved in the planning were persuaded a British response would take place. ${ }^{63}$ Furthermore, on $23 \mathrm{March}$, one day before DDay was established, the General Staff produced a document identifying "six different capacities, from non-reaction to reaction with an important task force." ${ }^{64}$ In other words, when the details of the landing were being discussed, the Argentine military predicted a British response in five out of six scenarios, and foresaw the reaction that effectively took place-proportional British reaction-as the most likely scenario.

Also damaging the miscalculation thesis is a second piece of evidence regarding the junta's decision to stay on a collision course before actual combat started. This demonstrates miscalculation was not the key cause behind the break in hostilities, since the military did not back down during the whole month from the deployment of the British task force on 3 April to the bombing of Puerto Argentino/Port Stanley on 1 May $1982 .{ }^{65}$ Argentine authorities had all the important pieces of information before hostilities broke out. The junta knew the United Kingdom would send

${ }^{60}$ CAERCAS, Informe Final, 734

${ }^{61}$ Ibid., 376.

${ }^{62}$ Rear Admiral Juan José Lombardo, Declarations to the CAERCAS, vol. 1, 57; Major General Osvaldo García, ibid., 2; Brigadier Martín Plessl, ibid., 38.

${ }^{63}$ Alfredo Luzuriaga, "La inteligencia estratégica naval en la Guerra de Malvinas: un éxito poco conocido," Boletín del Centro Naval 835 (January-April 2013): 71-78. See Appendix 1 for a list of the reports.

${ }^{64}$ Rear Admiral Leopoldo Suarez del Cerro, Declarations to the CAERCAS, vol. 1, 147.

${ }^{65}$ John Arquilla and María Moyano Rasmussen, "The Origins of the South Atlantic War," Journal of Latin American Studies 33, no. 4 (November 2001): 750-54. Two intelligence assessments made after the landing, on 6 and 28 April, further warned of the imminence of war. Cf. CAERCAS, Informe Final, 220. 
naval forces and could count on the support of the United States since before the occupation, on 1 April, when the Argentine ambassador in Washington, Esteban Takacs, communicated to his government that Secretary of State Alexander Haig knew of the mobilization of troops and declared the United States would side with Britain in case of a conflict. ${ }^{66}$ That same night, President Ronald Reagan called Galtieri to make this point even more explicit. The Argentine president responded steadfastly: "England should recognize our sovereignty tonight." ${ }^{37}$ In the following weeks, with the British fleet sailing south, Argentine authorities rejected at least four proposals that would have prevented the hostilities and a more favorable outcome than military defeat: United Nations Security Council Resolution 502, General Haig's mediation, a mediation by Peruvian president Fernando Balaúnde Terry, and another by United Nations SecretaryGeneral Javier Pérez de Cuellar. ${ }^{68}$ Instead, Galtieri's inflammatory rhetoric doomed the negotiations. On 10 April, when Haig arrived with a proposal, Galtieri went out to the balcony of Casa Rosada (seat of the Argentine national government) and publicly said: "If they want to come let them come, we will present battle." ${ }^{69}$

Finally, a third piece of evidence suggests miscalculation was not a necessary cause of the invasion: Recently declassified documents confirm the junta was ready to open a second front with Chile. ${ }^{70}$ The war scenario on two fronts is categorized as "very feasible" in the strategic military planning documents prior to the Malvinas War. In particular, DEMIL 1 established that the potential military reaction of the United Kingdom would be confronted without affecting the capabilities committed to the Chilean front. ${ }^{71}$ This created several problems for the army, such as having to deploy conscripts-some of them with no proper instruction or training-instead of experienced mountain regiments that were better prepared for the weather conditions in the islands. Then, at the meeting of the Military Committee

\footnotetext{
${ }^{66}$ Ambassador Esteban Tacaks, Declarations to the CAERCAS, vol. 2, 205.

${ }^{67}$ Brigadier General Basilio Lami Dozo, Declarations to the CAERCAS, vol. 4, 818

${ }^{68}$ For an explanation of how these proposals were better than military defeat for Argentina's claims, see Ambassador Carlos Ortiz de Rozas, Declarations to the CAERCAS, vol. 3, 578. Ortiz de Rozas was the Argentine ambassador to the United Kingdom and one of the Argentine diplomats with the most knowledge about British politics and the Malvinas claim. Nevertheless, he was completely sidelined from the negotiations after late 1981 and was surprised by the landing just as anyone else. The junta had also tried to replace him with Rear Admiral Rodolfo Luchetta-a naval official close to Anaya -in December 1981. This provides further indication that the decision to go to war was already decided by then.

${ }^{69}$ Lieutenant General Leopoldo F. Galtieri, Declarations to the CAERCAS, vol. 4, 695.

${ }^{70}$ Martin Middlebrook, Task Force: The Falklands War, 1982 (London: Penguin, 1987), 36; Daniel K. Gibran, The Falklands War: Britain versus the Past in the South Atlantic (Jefferson, NC: Macfarland, 1998), 65-66; Kalevi J. Holsti, The State, War, and the State of War (New York: Cambridge University Press, 1996), 160. The Argentine Ministry of Foreign Affairs from March to December 1981 assessed: "The military planning was, with the Falklands in Argentine hands, to invade the disputed islands in the Beagle Channel. That was the determination of the navy." Oscar Camilión, Memorias Politicas: De Frondizi a Menem, (Buenos Aires: Editorial Planeta, 1999), 281.

${ }^{71}$ Argentine Government, DEMIL 1/82, 4.
} 
on 16 March 1982, a work plan was approved that anticipated several scenarios and "the most dangerous of all: reaction with an important task force connected to Chile." 72 This over preparedness on the Chilean front directly contradicts the under preparedness implied in the miscalculation thesis.

Overall, three key counterfactual statements implied in the diversionarywar thesis, and another three counterfactuals contained in the miscalculation thesis, are falsified by the facts upon close scrutiny. In the language of process tracing, this section had proposed six "hoop tests," that is, tests that "propose that a given piece of evidence from within a case should be present for a hypothesis to be true." ${ }^{73}$ When the implications of a theory are this transparent, "failing a hoop test counts heavily against a hypothesis." 74 Given that the Malvinas/Falklands War is often presented as a paradigmatic case of the diversionary-war thesis, the analysis presented above has important implications beyond this case. ${ }^{75}$

If the two prominent explanations for the Malvinas/Falklands War are not borne out by evidence, what explains this case? One alternative story proposes that the fundamental factor leading to the war was the shrinking power gap between the United Kingdom and Argentina. ${ }^{76}$ Proponents of this thesis argue the junta accurately believed that taking the islands by force was feasible, but lost the war due to certain organizational pathologies of the Argentine military. ${ }^{77}$ This narrative does a better job in focusing on long-term structural trends instead of mere domestic factors, yet it faces equally serious problems. If the junta perceived they were narrowing the gap, why not simply wait for further British decline ${ }^{78}$ Most importantly, newly declassified evidence contradicts this thesis in two important ways.

\footnotetext{
${ }^{72}$ Rear Admiral Suarez del Cerro, Declarations to the CAERCAS, vol. 1, 147.

73 James Mahoney, "Process Tracing and Historical Explanation," Security Studies 24, no. 2 (April-June 2015): 207.

${ }^{74}$ Ibid., 208.

${ }^{75} \mathrm{Cf}$. M. Taylor Fravel, "The Limits of Diversion: Rethinking Internal and External Conflict," Security Studies 19, no. 2 (April-June 2010): 307-41. In hindsight, however, our findings are in line with the long-held belief that diversionary-war theory, although reasonable, finds little empirical suport when put to the test. See Giacomo Chiozza and Henk E. Goemans "Avoiding Diversionary Targets" Journal of Peace Research 41, no. 4 (July 2004): 423-43. As one author put it, "Seldom has so much common sense in theory found so little support in practice." Patrick James, cited in Jaroslav Tir, "Territorial Diversion: Diversionary Theory of War and Territorial Conflict," Journal of Politics 72, no. 2 (2010): 413-25, quote on 413. Given all the aforementioned evidence against the diversionary-war thesis one might ask why it has taken such a strong hold. We speculate that this story may be more appealing because the invasion happened only three days after one of the first big demonstrations against the government. Cognitive psychologists have also found that counterfactual reasoning is often built over default perceptions of truth and that individuals tend to look at events that are temporally close to the outcome (that is, constant conjunction) to infer causality. These tendencies are accentuated when we need to explain a puzzling event in the lack of alternative hypotheses. Kahneman and Tversky, "Prospect Theory."

${ }^{76}$ Others have reviewed a few other explanations and highlighted their respective weaknesses. See, for example, Oakes, "Diversionary War and Argentina's Invasion of the Falkland Islands," 443-48.

${ }^{77}$ Arquilla and Moyano, "The Origins of the South Atlantic War."

${ }^{78}$ To their credit these authors recognize the optimal moment for the invasion would have been after 15 May, when the winter would have prevented a British deployment and some British ships would have been decommissioned. See ibid., 761. However, their theory does not explain the suboptimal timing of the invasion, a major challenge to their argument.
} 
First, testimonies unanimously point to the prospects that more British ships would be deployed in the South Atlantic as the immediate trigger of the decision to invade on 2 April, suggesting that, for the junta, the window of opportunity was closing and not opening or, in other terms, the gap was widening instead of shrinking. Second, not a single official testifying to the Rattenbach Commission claims victory against the United Kingdom was believed to be possible. Galtieri thought the islands could be "defended for limited time,"79 Anaya thought "we could never win a war against Great Britain," ${ }^{80}$ and finally Brigadier-General Basilio Lami Dozo, the third member of the junta, virtually laughed at the insinuation: "How could we even think of a military confrontation?" ${ }^{\prime 1}$

We may therefore ask: If the junta knew the United Kingdom would almost certainly defeat Argentina in war, and they knew that Britain would fight that war, why did they stay on a collision course, denying the realities before their eyes?

In the next section we develop our alternative explanation, which emphasizes Argentina's decline and, in turn, how the early decisions the Argentine military made set them on a self-reinforcing risk-acceptant path that prevented a rational, negotiated solution. The story we propose has counterfactuals of its own, which we make explicit from the outset to facilitate the analysis and show the greater consistency of our argument.

\section{Prospect Theory and the International Behavior of Declining Argentina}

Consistent with prospect theory, we argue that leaders of declining states may adopt costly and risky military strategies and protract them despite their decreasing utility. Our framework, succinctly illustrated in Figure 1, can elegantly explain the Malvinas/Falklands enigma. We argue in this section that Argentina's risk-acceptant foreign policy resulted from its long decline relative to peer competitors. As foreign policy elites and the general populace internalized this decline, the loss of the Malvinas/Falklands to Britain becomes an important reference point against which they measured Argentina's possible resurgence. This powerful loss frame influenced the military junta and, absent the de-biasing mechanisms of a less-insulated regime, it accepted the risk of reclaiming the territory and instigated the war.

In our narrative, we implicitly follow a method of sequence elaboration ${ }^{82}$ in which the Argentine decline is necessary for the military to adopt a loss

\footnotetext{
${ }^{79}$ Lieutenant General Galtieri, Declarations to the CAERCAS, vol. 4, 697.

${ }^{80}$ Admiral Anaya, ibid., 765.

${ }^{81}$ Brigadier General Lami Dozo, ibid., 817.

${ }^{82}$ James Mahoney, Erin Kimball, and Kendra Koivu, "The Logic of Historical Explanation in the Social Sciences," Comparative Political Studies 42, no. 1 (January 2009): 114-46.
} 

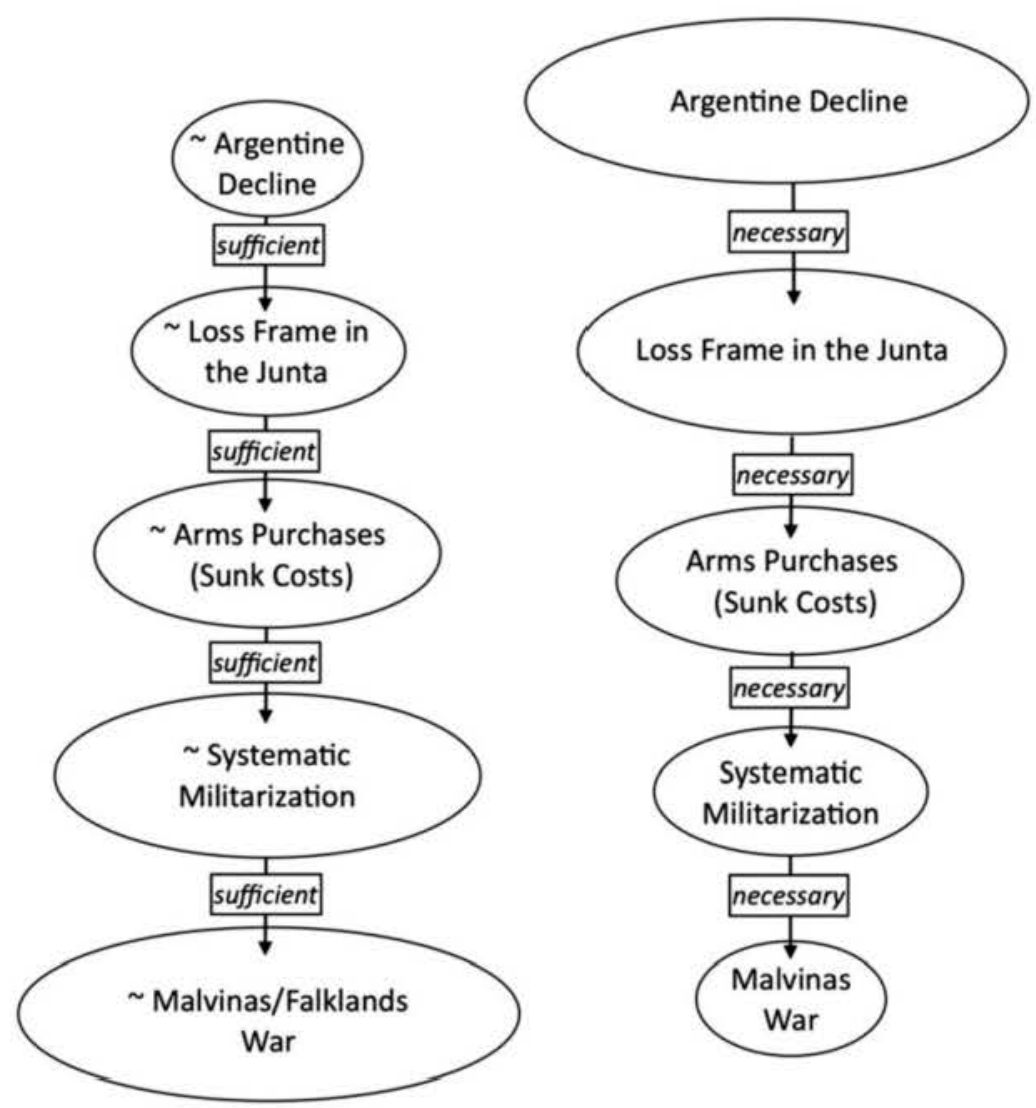

Figure 2. A set-theoretic counterfactual analysis of the Malvinas/Falklands War.

frame, which in turn is necessary for heavy investment in arms, riskacceptant behavior and, finally, war. Such a set-theoretic approach may be visualized with necessary conditions as supersets of their implications. Taken together, ours is an INUS condition counterfactual, meaning the conditions previous to the outcome are "insufficient but non-redundant component(s) of a combination of conditions that is unnecessary but sufficient for an outcome." 83 Using an INUS condition counterfactual emphasizes that we are explaining one specific causal path to war and that these conditions are necessary for that specific causal path.

Our central claim can be stated as follows: although domestic unrest and misperception were not necessary conditions for the outbreak of hostilities, individually the Argentine decline, the prevalence of a loss frame, the sunk costs produced by excessive military expenditure, and the risk-acceptant nature of the strategic behavior that followed were necessary for the next link in the chain to occur. Put together, decline, anxiety, "sunk"

${ }^{83}$ James Mahoney and Rodrigo Barrenechea, "The Logic of Counterfactual Analysis in Case-Study Explanation," British Journal of Sociology 70, no. 1 (January 2017): 314. 
investment, and risky behavior were a sufficient combination for the invasion, although other combinations could have led to the outcome as well. ${ }^{84}$ Figure 2 shows the logic of our case-specific argument and the counterfactual claims we are making.

In Figure 2 we make another implication of our argument clear. Each time we say a factor is necessary for another to occur, we are simultaneously implying that the absence (denoted by $\sim$ ) of the former is sufficient for the absence of the latter. For example, stating Argentina's fall was necessary for the consolidation of a loss frame amounts to affirming that, without this decline, the kind of thinking predicted by prospect theory would not have predominated. Importantly, in counterfactual analysis the necessity of each link is assessed according to the realities of the case, by creating a "possible, parallel, or alternate world" in which only the antecedent did not occur but all other features of the case are held constant. ${ }^{85}$ We make clearer the case-specific nature of our necessity claims by slightly changing the label of our conditions from Figure 1 to Figure 2.

Figures 2 makes the assumptions of our own counterfactual explicit. Consequently, in the next few sections we concern ourselves with showing not only the presence of the factors that are key to our story but also these relationships of necessity and sufficiency. In doing so, we demonstrate through counterfactual analysis that our own hypothesis is not vulnerable to the kind of problems we found with the miscalculation and diversionary-war theses.

\section{Power Shift}

The background cause of the conflict in the Malvinas/Falklands was Argentina's relative decline vis-à-vis peer competitors in its region. It is a well-known fact that Argentina was a declining power by the mid-twentieth century. ${ }^{86}$ As Figure 3 shows, countries once comparable to Argentina, like Brazil and Mexico, ${ }^{87}$ broadened their material capabilities gap, whereas smaller neighbors like Chile narrowed this difference. In a ranked listing of the world's largest economies, Argentina fell from the 8th to the 22nd position from 1960 to 1980 .

\footnotetext{
${ }^{84}$ The structure of our counterfactual resembles that of Robert English, "Perestroika without Politics: How Realism Misunderstands the Cold War's End," in Explaining War and Peace: Case Studies and Necessary Condition Counterfactuals, ed. Gary Goertz and Jack S. Levy (London: Routledge, 2007). Cited in Mahoney and Barrenechea, "The Logic of Counterfactual Analysis in Case-Study Explanation," 320-22.

${ }^{85}$ Jack S. Levy, "Counterfactuals, Causal Inference, and Historical Analysis," Security Studies 24, no. 3 (July-September 2015): 379.

${ }^{86}$ See Carlos Escudé, "The Argentine Eclipse: The International Factor in Argentina's Post-World War II Decline" (PhD diss., Yale University, 1981). See also Schenoni, "The Argentina-Brazil Regional Power Transition."

${ }^{87}$ Mexico is geographically distant from Argentina but a peer competitor in multilateral fora, where the two countries have historically disputed the leadership of Hispanic America.
} 


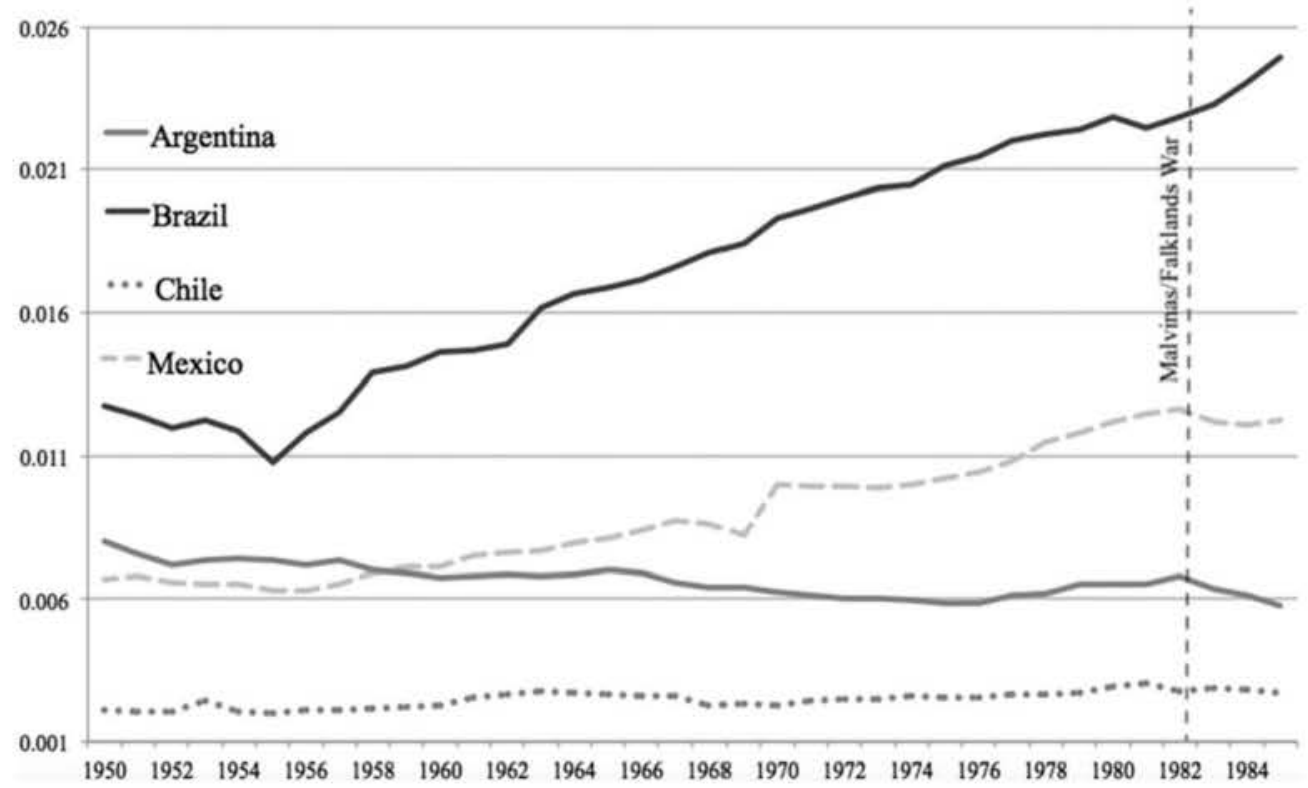

Figure 3. Argentina's relative decline in material capabilities, $1950-85{ }^{88}$ Notes: The vertical axis represents the percentage of the world's material capabilities that correspond to each of these countries. This Composite Index of National Capabilities is based on six indicators of international power: energy consumption, iron and steel production, military expenditure, military personnel, total population, and urban population.

The sharp decline of Argentina led to further concerns about status and prestige that are transparent in the thinking of the junta members. One of the main characteristics of the military regime's foreign policy was "an expansive nationalism that pretended to reorder the position of Argentina in the world and in the Latin American context." ${ }^{\prime 99}$ In his deposition to the Rattenbach Commission, Anaya says the junta believed "Argentina would regain leadership in Latin America by having a dignity that for years, for many years, it had not." 90

In this context, a series of setbacks related to active territorial disputes were interpreted as concrete affronts to Argentina's regional standing. In 1977, Queen Elisabeth II awarded three islands in the Beagle Channel to Chile in an arbitral award, which the Argentine government declared null but made the recovery of the islands by legal means almost impossible. In 1979, the military government made concessions to Brazil in the Tripartite Agreement of Corpus-Itaipú, which hard-liners interpreted as surrendering the control over the flow of the Parana River to an old foe. Argentines also

\footnotetext{
${ }^{88}$ Correlates of War, Composite Index of National Capabilities.

${ }^{89}$ Ricardo Domínguez Ruiz, "Las relaciones Argentina-Estados Unidos: 1976-1980" (PhD diss., Universidad Nacional Autónoma de México, 1983), 98. See also Magdalena Lisinśsa, Argentine Foreign Policy during the Military Dictatorship, 1976-1983 (London: Palgrave Macmillan, 2019).

${ }^{90}$ Admiral Anaya, Declarations to the CAERCAS, vol. 4, 738.
} 
had high hopes that decolonization would allow the reincorporation of the Malvinas, but the process was reaching a global impasse, and negotiations with Great Britain stalled during the Margaret Thatcher's Conservative administration.

\section{Loss Frame}

Having suffered decline relative to its peer competitors and concrete territorial losses, Argentine elites failed to renormalize their reference point in interpreting their country's regional standing. This is consistent with prospect theory, which considers that individuals making decisions amid heavy losses tend to evaluate their current situation not based on the objective status quo but on the status quo ante. It is also a phenomenon that has caught the attention of many Argentine social scientists. According to a "dismembered power" or "fantastic Argentina" narrative that became prevalent during the 1960s, despite its huge territorial extension at the moment of its independence, Argentina had suffered a slow process of territorial "dismemberment" by the action of neighboring states and extraregional powers. ${ }^{91}$ In this view, Argentina would have been a great power had it kept the current territories of Peru, Bolivia, Paraguay, Uruguay, and a large part of Chile that belonged to the Viceroyalty of the Rio de la Plata (1776-1814), whose capital was Buenos Aires. ${ }^{92}$

Primary and secondary education systems increasingly diffused the "fantastic Argentina" and "dismembered power" frames in the decades leading to the Malvinas/Falklands War. ${ }^{93}$ During the 1950 s, the cartographic school adopted those concepts defining Argentina as a nation in constant retreat and Chile as an expansionist state. ${ }^{94}$ This vision was consolidated through the Atlas of Territorial Development of Argentina, supported by the main academic and scientific institutions of the country and distributed widely through the country's schools. Its introduction stated the main objective of the work was "to highlight the contours of the territory that the Viceroyalty of the Rio de la Plata had at the time when Argentina became independent from Spain (to serve as) the basis to apply the doctrine of the uti possidetis (as you possessed, thus may you possess)."

\footnotetext{
${ }^{91}$ Pablo Lacoste, La imagen del otro en las relaciones internacionales de la Argentina y Chile 1534-2000 (Buenos Aires: Fondo Cultura Económica, 2003), 265-300.

${ }^{92}$ Vicente Palermo, Sal en las heridas: Las Malvinas en la cultura Argentina contemporánea (Buenos Aires: Editorial Sudamericana, 2007), 16-25.

${ }^{93}$ Carlos Escudé "Contenido nacionalista de la enseñanza de la geografía en la República Argentina 1879-1986," in Malvinas hoy: herencia de un conflicto, ed. Atilio Boron and Julio Faúndez (Buenos Aires: Puntosur, 1989); Carlos Escudé, "El trasfondo cultural de la invasión argentina de Malvinas."

${ }^{94}$ Lacoste, La imagen del otro en las relaciones internacionales de la Argentina y Chile 1534-2000, 373-74.

${ }_{95}^{95}$ Patricio Randle, Atlas del desarrollo territorial de la República Argentina (Buenos Aires: Oikos, 1981), 5.
} 
These territorial losses loomed large in the minds of military leaders, who linked them with state survival from 1960s onward. That neighboring states were always on the lookout, waiting for an opportunity to prey on Argentina, was a main assumption. ${ }^{96}$ An exponent of this view argued that "Chile is a country that has been in the law of expansion since the era of South American emancipation; Argentina in the law of resistance." ${ }^{97}$ Another representative voice complained about the "expansive impetus of Chile at the expense of our country." 98 This contributed to the view that the loss of the islands in the Beagle Channel would be one more in a series of losses to Chile, which in turn hardened the Argentine position.

The vision of the Malvinas as part of this "amputated" territory ${ }^{99}$ resurfaced in the twentieth century after many decades of acquiescence beyond the formal diplomatic claim. ${ }^{100}$ A key figure in the transformation of Malvinas into a popular cause was Alfredo Palacios, a socialist senator who championed the cause of regaining Argentine sovereignty in the 1930s. But the idea of Malvinas as a "territorial loss" came to occupy a central place in politics only in the 1960s and 1970s. ${ }^{101}$ It was then that Argentina's decision makers started to believe "Argentina was incomplete if the islands were not recovered." ${ }^{102}$ While this vision arguably pervaded all Argentine political elites, ${ }^{103}$ the "dismembered power" loss frame was particularly strong in the armed forces, and the Malvinas/Falkland Islands became a clear focal point for the military.

This argument demonstrates that it was not only a "military mindset" about the use of force that led to the conflict ${ }^{104}$ but a military leadership deeply affected by a long pattern of country decline and the accompanying sense of loss. Probably the most important link in the chain of events

\footnotetext{
${ }^{96}$ Farid Kahhat, Tras la Guerra Fría: Mentalidad militar y políticas de seguridad en Sudamérica (Lima: Fondo Editorial del Congreso del Perú, 2007), 92. An exponent of this view argued that "Chile is a country that has been in the law of expansion since the era of South American emancipation; Argentina in the law of resistance." César José Marini, La crisis en el Cono Sur (Buenos Aires: Pleamar, 1984), 91. Another representative voice complained about the "expansive impetus of Chile at the expense of our country." Jorge Fraga, "Argentina y los principios de la geopolítica," Estrategia 58 (1979): 124.

${ }^{97}$ Marini, La crisis en el Cono Sur, 91.

${ }^{98}$ Fraga, "Argentina y los principios de la geopolítica," 124.

${ }^{99}$ Federico Merke, "The Malvinas Conundrum," British Politics Review 15, no. 1 (Winter 2018): 14.

${ }^{100}$ Rosana Guber, "Alfredo Lorenzo Palacios: honor y dignidad en la nacionalización de la causa Malvinas," Revista de Ciencias Sociales 10 (1999): 83-116.

${ }^{101} E s c u d e ́$, "Contenido nacionalista e la enseñanza de la geografía en la República Argentina 1879-1986," 196.

${ }^{102}$ Palermo, Sal en las heridas, 177.

${ }^{103}$ The leader of the main prodemocratic party affirmed a few days after Operation Sovereignty: "Historically, Argentina has been excessively generous in its proposals of limits and has given away a lot of territory... We are here to tell them no... Argentina, unfortunately, cannot go back, it is at the limit of its tolerance and sometimes we will have to say no, and this time we have said it, because we cannot fall into the sea." Carlos Escudé and Andrés Cisneros, Historia general de las relaciones exteriores de la República Argentina, vol. 13 (Buenos Aires: Grupo Editor Latinoamericano, 2000), 294. Additionally, the editorial of the largest newspaper in Argentina noted the day after the landing: "Argentine troops went to restore the national honor ... reconquering of a fragment of the Fatherland, whose absence was a mutilation." Palermo, Sal en las heridas, 179. Italics in original.

${ }^{104}$ Jessica L. P. Weeks, Dictators at War and Peace (Ithaca, NY: Cornell University Press, 2014), 115.
} 
leading to the invasion of the islands was the consolidation of a military faction ${ }^{105}$ determined to bring Argentina back to its former international status ${ }^{106}$ and insulated from other actors within the government.

In the Rattenbach interviews, all three members of the junta mention, at one point or another, that Argentina was in decline and under threat, and actions had to be taken to restore its status. It is natural that a loss frame would come to predominate at the top levels of the state after the 1976 military coup given the junta's insulation from mechanisms within the state that may have otherwise tempered these cognitive biases. The insularity and secrecy of the junta's decision making is hard to overstate. When the invasion decision was made in January, no more than ten individuals-all of them military officers-knew about these plans. The number of individuals involved had risen only to sixteen by 16 March, two weeks before landing-the only civilian involved being the minister of foreign relations. ${ }^{107}$ Because of the flexible institutional framework of the Proceso de Reorganización Nacional (PRN) - the name adopted by Argentina's last military dictatorship (1976-83) - the junta could exclude many civilians. The minister of defense, for example, should have been part of the Military Committee from the beginning according to the National Defense Act. Asked about this anomaly, Galtieri responded that the minister of defense was excluded precisely due to his "condition as a civilian and particular training," to which Rattenbach keenly noted: "Wouldn't the presence of a civilian mindset have been useful for three military minds?"108 The obscurity and secrecy of the junta's decision looms large in the Rattenbach report as one of the main causes of the war.

\section{Sunk Costs}

For Argentina to fight a war over the Malvinas/Falklands, the Argentine junta had to have enough troops and arms to fight it. In this section, we note the importance of significant Argentine defense procurements-and accompanying psychological effects of unrecoverable investment-that would not have taken place in the absence of a military government imbued by a loss frame. Cognitive theory expects the investments made in a particular policy to influence future decisions heavily after losses. This suggests the investments made in the 1970 s would have entered the

\footnotetext{
${ }^{105}$ David Pion-Berlin, Through Corridors of Power: Institutions and Civil-Military Relations in Argentina (Philadelphia: Pennsylvania State University Press, 1997).

${ }^{106}$ Roberto Russell, "Las relaciones Argentina-Estados Unidos: Del 'alineamiento heterodoxo' a la 'recomposición madura,"' in Continuidad y cambio en las relaciones América Latina/Estados Unidos, ed. Monica Hirst (Buenos Aires: Grupo Editor Latinoamericano, 1987), 24-45.

${ }^{107}$ Francisco Fernando Santibañes, "The Effectiveness of Military Governments during War: The Case of Argentina in the Malvinas," Armed Forces and Society, 33 no. 4 (July 2007): 612-37.

${ }^{108} \mathrm{General}$ Galtieri, Declarations to the CAERCAS, vol. $4,692$.
} 
strategic calculus in scenarios like the Beagle and Malvinas/Falklands crises, respectively, as sunk costs. ${ }^{109}$

Due to the strategic thinking directly derived from the aforementioned loss frame, Argentina rapidly modernized its armed forces in the 1970s, buying two submarines from the United States in 1974, four destroyers from Germany in 1978, and two more from the United Kingdom in 1977 and 1981. Considering the bulk of the Argentine navy at the time of the invasion was composed of one aircraft carrier, one cruiser, seven destroyers, and four submarines, ${ }^{110}$ it is reasonable to conclude that had Argentina not bought these ships, the prospects of a successful invasion would have been meager. ${ }^{111}$ The number of combat aircraft-a technology that proved key during the war-also increased dramatically during the military dictatorship, from 132 planes to a figure somewhere between 174 and 216 . Battle tanks also increased, from 120 to $185 .^{112}$

These investments not only resulted in quantitative increases but also a qualitative enhancement of the combined operational capacity of the military. By the mid-70s, the Argentine armed forces were the sole military in Latin America that could deploy a naval combat group with an aircraft carrier equipped with fifteen A-4Q fighters plus eight escort destroyers, among them one British-made Type 42 , the most advanced at that time. In addition, the Navy had two German submarines of class Type 209, which were state-of-the-art machines. In comparison, Chile did not have an aircraft carrier and Brazil had the Minas Gerais, which could only operate with helicopters. Likewise, no country possessed last-generation destroyers, and their submarines were, for the most part, models from the Second World War.

To these capabilities would be added, at the beginning of the 1980s, the duo Super Éterndart/Exocet, which gave the Argentina Naval Aviation great offensive power. The air force, for its part, had last-generation combat planes, such as the Mirage III, the Mirage V Dagger, and the A-4C aircraft. Neither the Brazilian nor Chilean force had aircraft in such quantity and quality. ${ }^{113}$ Likewise, the army had achieved a high level of self-sufficiency in the production of weapons because of the implementation of the Europe Plan, which boosted the national production of tanks, heavy artillery,

\footnotetext{
${ }^{109}$ Marcelo Rougier "El Complejo Militar-Industrial, "núcleo duro" del estado empresario y la industrialización en la Argentina," in Los derroteros del Estado empresario en la Argentina siglo XX, ed. Marcelo Rougier and Andrés M. Regalsky (Buenos Aires: Eduntref, 2015).

${ }^{110}$ International Institute of Strategic Studies (IISS), The Military Balance 1979-1980 (London: IISS, 1979). Cf. Arquilla and Moyano, "The Origins of the South Atlantic War," 756.

${ }^{111}$ For example, all the technology of the Argentine navy would have been comparable to that of the ARA General Belgrano-the Argentine ship without antisubmarine technology that was easily and disgracefully sunk outside the exclusion zone during the first day of combat.

112IISS, The Military Balance 1981-1982 (London: IISS, 1982). Cf. Arquilla and Moyano, "The Origins of the South Atlantic War," 756

${ }^{113}$ IISS, The Military Balance 1981-1982.
} 


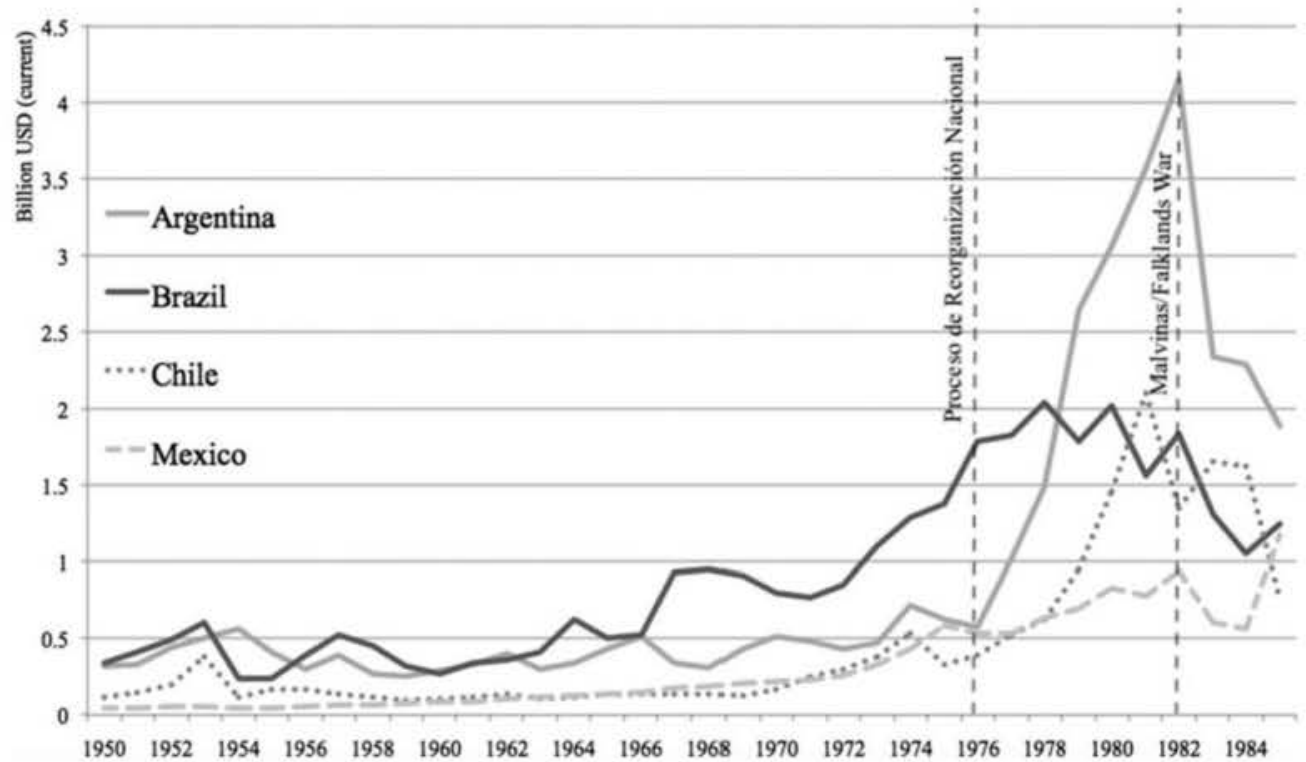

Figure 4. Argentina's relative rise in military expenditures, $1950-85 .^{116}$

mortars, communications equipment, ammunition, rifles, and machine guns, among others items. ${ }^{114}$

Figure 4 depicts the respective evolutions of the defense budgets of Argentina and the three Latin American countries in Figure 3. A first vertical dashed line marks the beginning of the PRN, and a second one marks the Malvinas/Falklands War. The figure shows exponential growth in military spending, "rapidly transforming the improbable into the inevitable," 115 which strengthens our counterfactual. In other words, had Argentina maintained its prior level of military expenditures, subsequent arm acquisitions and reckless militaristic behavior would have been "improbable." Moreover, the greatest relative increase in expenditures clearly took place far before the war, between 1976 and 1979.

Different documents and declarations of high-ranking military officers reveal a generalized perception that Argentina had exceptionally and temporarily become a military power. ${ }^{117}$ The chief of staff of the army declared: "The Army has reached a doctrinal and organic maturity that places it at the level of the most advanced in the world." ${ }^{118}$ In the depositions

\footnotetext{
${ }^{114}$ Rosendo Fraga, Ejército: del escarnio al poder (1973-1976) (Buenos Aires: Planeta, 1988), 19-20.

${ }^{115}$ Philip E. Tetlock and Aaron Belkin, "Counterfactual Thought Experiments in World Politics: Logical, Methodological, and Psychological Perspectives," in Counterfactual Thought Experiments in World Politics: Logical, Methodological, and Psychological Perspectives, ed. Philip E. Tetlock and Aaron Belkin (Princeton, NJ: Princeton University Press, 1996), 20.

${ }^{116}$ Correlates of War, Composite Index of National Capabilities.

${ }^{117}$ The understanding that the window of opportunity to translate its military superiority into territorial gains was closing was derived from the realization that Argentina could not maintain military expenditures as high as 4 percent of its gross domestic product indefinitely.

${ }^{118}$ Fraga, Ejército, 61-62.
} 
to the Rattenbach Commission, it is clear that Lami Dozo ${ }^{119}$ and Galtieri ${ }^{120}$ were aware of the huge investment the country made in those technologies, and they felt the need to put them into use before they became obsolete or out of date. Anaya thought, "The punishment that we could inflict (on the British fleet) was very great $\ldots$ and that in the time being that could not be resisted by Great Britain."121 The idea, given the huge investment Argentina had made in the previous decade-that is, given sunk coststhat the military was compelled to take the opportunity, was "well known at the level of the naval operational command." 122

\section{Risk Acceptance}

Argentina's relative decline to its peer competitors and territorial losses, plus the accompanying sense of loss the decline instilled in the military junta, all contributed to the type of offensive planning and high military investments ultimately necessary for the military to back risky attempts of militarization.

Figure 5 depicts the increase in the number of militarized interstate disputes (MIDs) involving Argentina during the period under analysis. ${ }^{123}$ This figure illustrates how Argentine armed forces were prone to produce episodes of militarization short of war with increasing frequency since the mid-1950s. Prominent examples include the unlikely militarization of the River Plate dispute with Uruguay ${ }^{124}$ and escalation with Brazil around the dispute over the construction of the Itaipú hydroelectric dam. ${ }^{125}$ As we have seen, Chile and Great Britain were frequently targets of these policies in the late 1970s.

Several aspects about these MIDs remain unseen in Figure 5 that are in line with our narrative. For example, 87 percent of post-1945 MIDs were related to territorial claims, and 78 percent had Argentina as the initiator. Also, according to the Correlates of War severity scale, MIDs in the decade preceding the war were two times as reckless as the average twentiethcentury MID. ${ }^{127}$ By looking at the risk assessment of Argentine strategic

\footnotetext{
${ }^{119}$ Brigadier Lami Dozo, Declarations to the CAERCAS, vol. 4, 810 .

${ }^{120}$ General Galtieri, ibid., 690.

${ }^{121}$ Ibid., 765.

${ }^{122}$ Ibid.

${ }^{123}$ Daniel M. Jones, Stuart A. Bremer, and J. David Singer, "Militarized Disputes, 1816-1992: Rationale, Coding Rules, and Empirical Patterns," Conflict Management and Peace Science 15, no. 2 (Fall 1996): 163-213.

${ }^{124}$ The most notable incident was the occupation of the island Timoteo Dominguez by Argentine forces on 13 January 1969. This was the most serious episode of militarization between these two countries in more than a century. Escudé and Cisneros, Historia general de las relaciones exteriores de la República Argentina, 89.

${ }^{125}$ Christopher Darnton, "A False Start on the Road to Mercosur: Reinterpreting Rapprochement Failure between Argentina and Brazil, 1972," Latin American Research Review 47, no. 2 (2012): 120-41; See also Schenoni, "The Argentina-Brazil Regional Power Transition."

${ }^{126}$ Correlates of War, Militarized Interstate Disputes Database, v4.3.

${ }^{127}$ Glenn Palmer, et al., "Updating the Militarized Interstate Dispute Data: A Response to Gibler, Miller, and Little," International Studies Quarterly (forthcoming).
} 


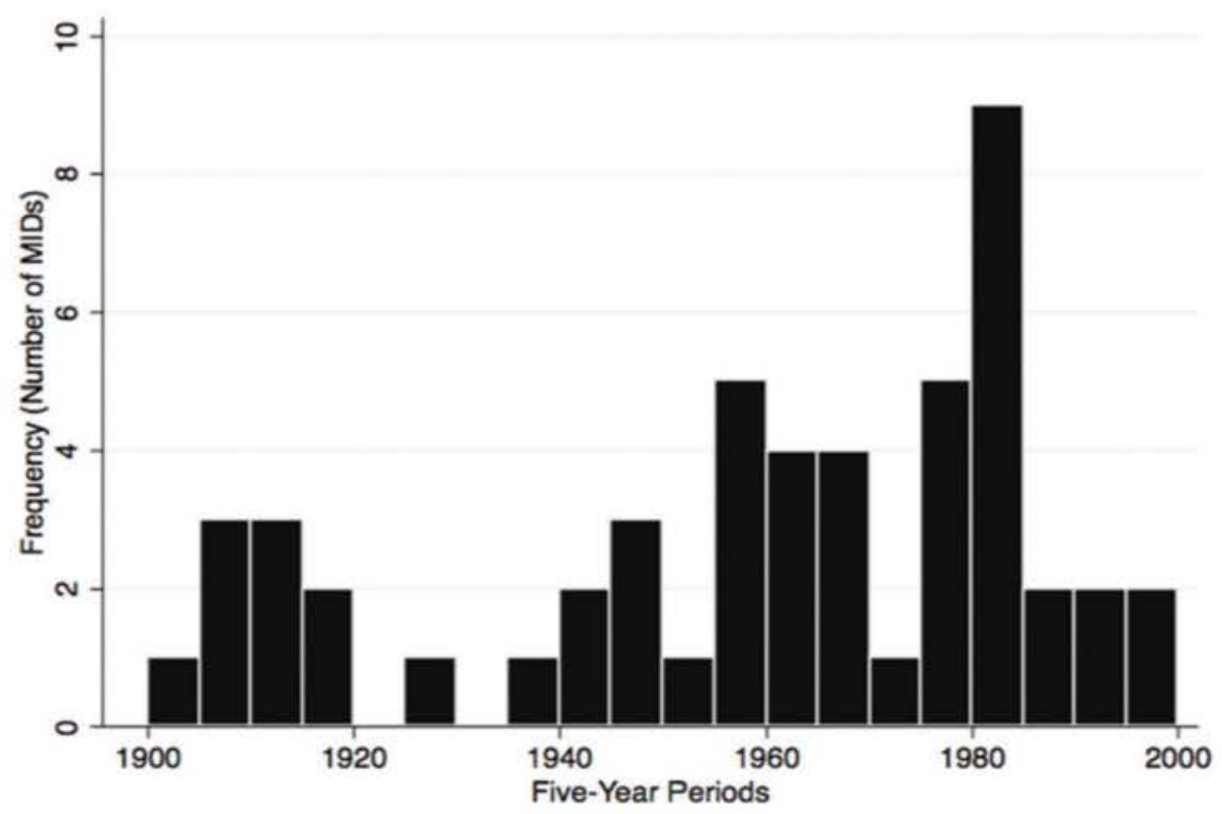

Figure 5. Militarized interstate disputes involving Argentina in the twentieth century. ${ }^{126}$

planners throughout the 1970 s, we can tell loss frames and sunk costs affected decision makers increasingly by the end of the decade. Operation Sovereignty is a case in point, ${ }^{128}$ but this is also the case of several plans that, fortunately, never took place. ${ }^{129}$

Statements by members of the Argentine military elite indicate the logic of risk acceptance became naturalized. In particular, given what was perceived as a relative success in the Thule Islands, the Navy planned to take similar actions in other territories. ${ }^{130}$ The commander of the Argentine fleet, Admiral Lombardo, stated: "In 1977 there was a lukewarm English reaction (to the establishment of a base in the Thule Islands). And since then that detachment was established, which meant a good contribution to our rights in the islands and in the Antarctic sector. Then I proposed a similar thing in the Georgias ... a scientific establishment, and then see if

\footnotetext{
${ }^{128}$ The invasion plans included not only the occupation of the islands but a generalized offensive over Chilean territory that entailed complete occupation in the course of a few days. Fortunately, the movement of the fleet was suspended twenty nautical miles off the coast of Chile due to a fierce storm, and the progress of the troops stopped after many Argentine platoons had entered Chilean territory. Bruno Passarelli, El delirio armado: Argentina-Chile, la guerra que evitó el Papa (Buenos Aires: Editorial Sudamericana, 1998).

${ }^{129}$ "Displaying the mentality of the Argentine military regime in the 1970 s, as another example, there was 'Plan Rosario,' according to which Argentina would attack the Malvinas and then turn to settle the Beagle Channel problem by force. The sequence, according to the plan, could also be reversed." Holsti, The State, War, and the State of War, 160.

${ }^{130}$ As David Mares points out, Argentines not only had the precedent of the Thule Islands but also studied previous episodes of coercive diplomacy such as the Suez Crisis of 1956, the Indian occupation of the Portuguese colony of Goa in 1961, and the unilateral declaration of independence of Rhodesia in 1965. The interpretation of these events was that the international community condemned the armed action at first, but they later accepted its consequences as fait accompli. See Mares, Violent Peace, 156.
} 


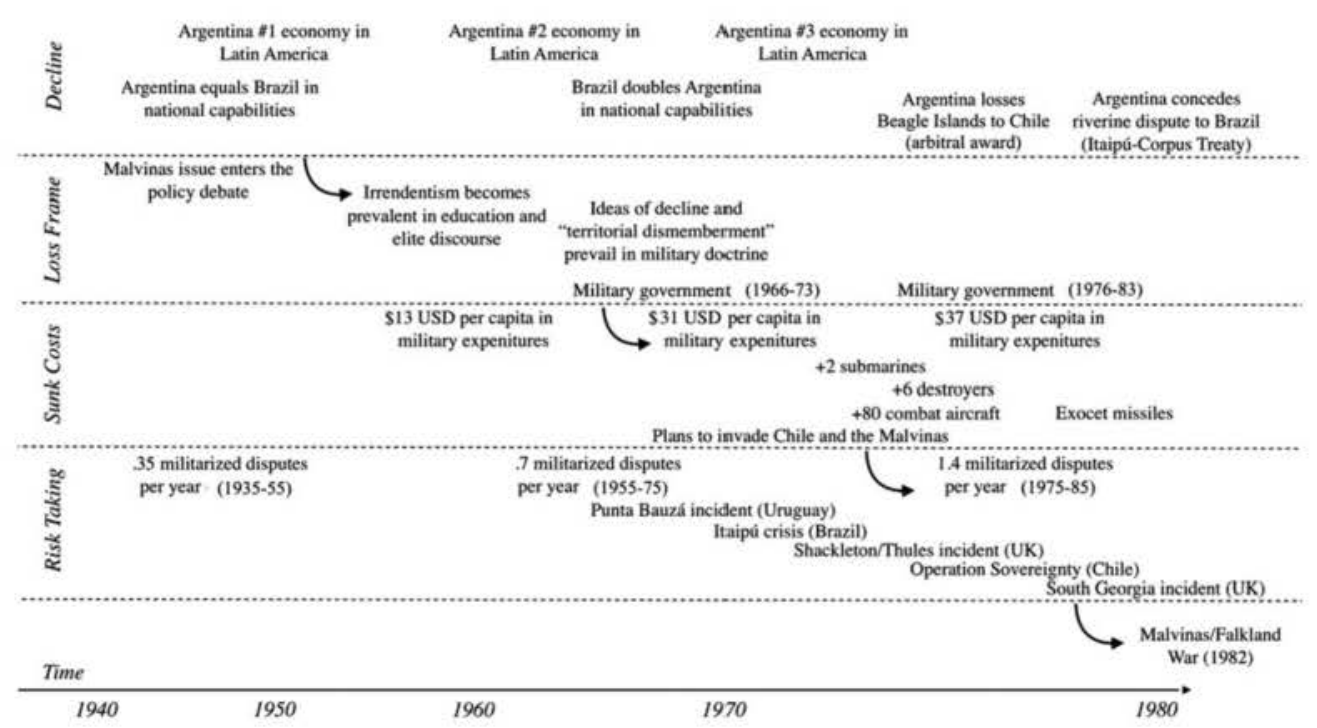

Figure 6. Event-history map: necessary conditions leading to the war.

we could progress in giving it the character of military occupation or political occupation."131

This nicely connects with the immediate trigger of the war: the South Georgia Island incident of March 1982, also known as the Davidoff Incident. In this episode, a group of Argentine scrap metal merchants raised a flag in the island, provoking a diplomatic crisis and the bilateral escalation that eventually led to the decision to take the Malvinas on 2 April. As Rear Admiral Alberto Vigo, member of the General Staff, told the Rattenbach Commission: "The Malvinas were occupied as a consequence of a series of incidents, graver and graver, which culminated in the decision to take the islands without thinking if the opportunity was good or bad."132

Figure 6 provides a succinct "event-history map,"133 an invariant and case-specific causal chain summarizing the narrative presented in this section in a way readily comparable with the causal mechanisms in Figure 1, with necessary conditions-or antecedent causes in the causal chain-taking place in the predicted sequence.

\section{Implications}

In this article we used recently declassified evidence from the Rattenbach Commission, the most comprehensive investigation on the causes and

\footnotetext{
${ }^{131}$ Admiral Lombardo, Declarations to the CAERCAS, vol. 1, 63.

${ }^{132}$ Rear Admiral Vigo, Declarations to the CAERCAS, vol. 2, 277.

${ }^{133}$ David Waldner, "Process Tracing and Qualitative Causal Inference," Security Studies 24, no. 2 (April-June 2015): 239-50.
} 
conduct of the Malvinas/Falklands War, to reinterpret the war's origins. In doing so, we provide two important contributions.

First, we show that the diversionary-war and miscalculation theses, which have been part of a mainstream narrative of the war, are fundamentally irreconcilable with new evidence. The Argentine military did not consider domestic politics in their strategic assesments and correctly foresaw-with impressive detail-a British response to the invasion. Our falsification of the diversionary-war thesis should be regarded as a particularly important contribution, as the Malvinas/Falklands is often a key example in that literature.

Second, we develop our own explanation based on prospect theory. In our account, Argentina's relative decline to peer competitors and territorial losses prompted its government-an insulated decision-making junta imbued by a loss frame-to engage in a long series of offensive, riskacceptant actions leading to the Malvinas/Falklands War. Put to the test against state-of-the-art set-theoretic conterfactual analysis, our account is entirely consistent with events leading to the war and the interpretation of key actors. This robust theory offers a potentially generalizable explanation of state behavior in contexts of relative power decline when tangible losses and insulated decision making allow for the rise and predominance of a loss frame.

The argument provides implications for future research. First, explanations for behavioral variation among states in decline is a worthy avenue for future scholarly inquiry. While some note that retrenchment is a wise grand strategic response for great powers in decline, further exploration of why some states choose to retrench and others do not would be beneficial. Second, our focus on regional power dynamics emphasizes the need for continued scholarship that tests the transitivity and limitations of theories well established at the level of great powers among minor powers. Third, we contribute to scholarship further exploring the conditions under which certain psychological or emotional theories of decision making operate in influencing state behavior. This article has demonstrated a particularly fruitful aspect of prospect theory's insights, specifically the stickiness of reference points among those who have incurred loss. Although reference points may be stickier in the domain of losses, there is little known about why actors may eventually renormalize them to the status quo or why some receive cognitive preeminence over others.

\section{Acknowledgments}

This manuscript benefited considerably from presentations at the Congress of the Argentine Society for Political Analysis (SAAP) on 6 August 2017 and University of Notre Dame's International Relations Workshop on 13 March 2018. Benjamin Denison, Carlos 
Escudé, Rosendo Fraga, Eugene Gholz, Ignacio Labaqui, Diego Leiva, Magdalena Lisińska, Dawisson Belem Lopes, Andrés Malamud, Fernando Mourón, Joseph Parent, Kimberly Peh Zi En, Francisco Santibañez, and Andrés Villar offered insightful comments. The authors are especially indebted to Gary Goertz and James Mahoney for their methodological guidance and to the Kellogg Institute for International Studies for supporting archival research in Buenos Aires and London during 2018 and 2019. The views expressed in this article are those of the authors and do not reflect the official policy or position of the US government or the Department of Defense.

\section{ORCID}

Luis L. Schenoni (D) http://orcid.org/0000-0001-6770-2136 